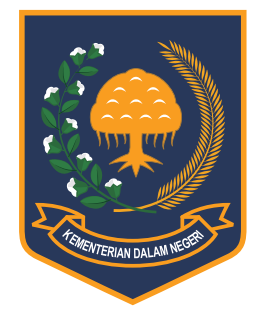

Jurnal Bina Praja 8 (2) (2016): 243-251

Jurnal Bina Praja

e-ISSN: 2503-3360 | p-ISSN: 2085-4323

Accreditation Number

735/AU2/P2MI-LIPI/04/2016

http://jurnal.kemendagri.go.id/index.php/jbp/index

\title{
THE IMPLEMENTATION OF ADMINISTRATIVE REGISTRATION on Population Migration (Case of Surabaya City, East Java Province)
}

\author{
Abdul Halik ${ }^{1, *}$ \\ ${ }^{1}$ Research and Development Agency, Ministry of Home Affairs (BPP Kemendagri) \\ Jl. Kramat Raya No. 132, Senen, Jakarta Pusat
}

Received: 15 September 2016; Accepted: 7 Oktober 2016; Published online: 30 November 2016

DOI: $10.21787 /$ jbp.08.2016.243-251

\begin{abstract}
The purpose of this study is to describe the policy implementation of administrative registration on population migration and the factors supporting and hindering the implementation of the policy in the city of Surabaya. The study uses a qualitative method. The result of this research shows that the policy implementation of administrative registration on population migration in the city of Surabaya for this is still classified as less good because there are still many weaknesses in its implementation. Potential factors supporting the implementation of administrative registration on population migration in the city of Surabaya is regulation clarity, adequacy of facilities, adequacy of costs, and the ability of the implementers. The factors inhibiting are the lack of community participation, low commitment to implementing, lack of executive officers, and the characteristics of the population.
\end{abstract}

Keywords: migration, administrating, population.

\section{INTRODUCTION}

In connection with the development, population and development are two terms that cannot be separated in the development process. Population information, either on the number, distribution, structure, and composition according to the various groups, is indispensable for a wide range of development planning. According to Ediastuti (2012: 18), demographic information that should be available for development planning not only in the form of data at the time of planning is made, but also needed the population information in times to come and in the past (historical).

In this regard, Kasto (2012: 11) asserts that for planning purposes, data from the census should be developed with certain assumptions that describe the state of the population in the future by or through the population projection. Determining this assumption is the key to the projection, either the assumption on the tendency of fertility, mortality, or migration. Thus, the population factor (population) is very important and necessary in the development process.

Although the role of population in development activities is quite strategic, but one of the phenomena (symptoms) of the population in Indonesia is that the population distribution is uneven (Mantra, 2012: 121), and also the process of urbanization is uncontrolled (Keban, 2012: 8). According to Davis and also Pernia, as quoted by Keban (2012: 9), urbanization is one of the symptoms of much attention today because not only related to the demographic problem but also have an important effect on the process of economic growth. Within certain limits, urbanization can drive, but the reverse can also hamper the development.

According to both demographic experts, positive relationship between the level of urbanization of a country, with a per capita income level of the related country, supported by empirical data on some countries, so as to give confidence

\footnotetext{
* Corresponding Author

Phone : +6281386529490

Email : liknph@yahoo.com
} 
that the urbanization has an important role in development. Thus, the implication is that in order to accelerate the development process, urbanization is necessary.

For the last two decades, cities in Indonesia have developed quite rapidly and this development will continue in the future (Effendi, 2012: 74). The embodiment of the city development is reflected in the high population growth, the rapid expansion of the city, the high rank of urbanization, the increase of economic development is characterized by the concentration of various economic activities, especially industries, modern services, and largescale trade.

To solve the population problem, the government issued a population policy since 1994 which among other things aimed at the improvement of the administration, registration, and population statistics in Indonesia (Wilopo, 2011: 36), and is currently based on Law No 24 of 2013 on the Amendment of the Law No 23 of 2006 concerning Population Administration. The target of the development of administrative registration and population statistics is the creation of a system for registration or registration of population to be more perfect, and gradually the population registration conducted throughout Indonesia. In addition, it is also directed to the availability of human resources quality in the field of civil registration which includes executive officers/registrars, data management apparatus, presenters, and analysts.

Urbanization, one of the causes of population problems in Surabaya, East Java Province, has become a complex national problem. As we know, the city of Surabaya is the second largest city in Indonesia and also the capital city of East Java Province. Like the other big cities, from year to year, the population of the city of Surabaya is growing. According to Central Statistics Agency (BPS: 2010) in Surabaya, the population growth from the year 2000 to 2010 is $0.66 \%$ and this number is expected to continue to rise. If we examine further the main cause of the growing number of the city population of Surabaya is not in the birth rate but from the coming population migration.

Based on the book of "Surabaya dalam Angka 2015" published by BPS of Surabaya City, the number of people born in 2014 was 46,405 people, while the population who come amounted to 65,048 people. In addition, according to the Department of Population and Civil Registration (Dukcapil) of Surabaya City, the number of people during the day can reach 5-6 million, while in the evening only about 3 million inhabitants. This indicates that many people are doing urbanization to Surabaya. The number of residents who do urbanization to Surabaya is not without reason. Many factors are drivers of this case. One of them is the high prospect in Surabaya, which is a centre of government, commerce, industry, etc.

To solve the problem of urbanization, Surabaya City Government would have to do crosssectoral cooperation with various agencies, both governmental non-governmental. If not controlled, Surabaya City will be negatively affected, either in the economic, social, cultural, or security sectors. One way to control urbanization is to curb administrative registration and registration of the population.

In general, the problem of the population of Surabaya city includes the low awareness of citizens to register, especially residents who are not permanent or seasonal residents. There are still many people who do not have ID cards and Family cards (especially migrants), there are people who are lazy to extend their identity cards, the marriages that are not registered/recorded because of the contracted marriage, the event of divorce that are not registered/recorded, there are still people who have double ID cards, or there are still cases of residential document forgery or falsification of ID cards and Family cards (Dispendukcapil of Surabaya City, 2015: 17-18).

The implementation of population administration policies that is coordinated and sustainable has a strategic value for governance, development, or service to the community, including to ensure the accountability of the public service in the field of population. It needs to be examined in order to provide constructive inputs to the government of Surabaya, which among other functions to organize community service activities or to coordinate the population administration or civil records (Capil).

Related to the above conditions, the problem in this research is: "How does the implementation of migration policy of administrative registration in Surabaya? The purpose of this study is to determine the implementation of the policy of the population migration administrative registration in the city of Surabaya.

Furthermore, the implementation of policies on population administration in Surabaya City refers to the regulation of Law No 24 of 2013 and the Surabaya City Regulation No 14 of 2014 on the Amendment of Surabaya City Regulation No 5 Year 2011 on the Implementation of the Population Administration. Population Administration is a series of planning and controlling activities on the issuance of documents or data via the Population Registry, Civil Registration, population information management, and the utilization of the results of the Population Administration for public services or development of other sectors (Article 1, Law No 24 of 2013).

Basically, of both regulations stated above, 
in order to realize a good national population administration, the Republic of Indonesia (NKRI), which is based on Pancasila and the Constitution of the Republic of Indonesia Year 1945, is essentially obliged to provide protection and recognition of the determination of the personal status and the legal status of any Event of Population and Milestones experienced by residents and/or Indonesian citizens are outside the Homeland.

In the context of the above population policy direction, then the goals of population policy in the city of Surabaya includes five (5) major points, namely: (a) the development of population quality; (B) controlling the population growth and quantity; (C) directing the mobility and distribution of the population; (D) the increase in administrative, registration, population statistics; and (e) the further utilization of the elderly population (Wilopo, 2012: 40). This study focuses only on the direction of mobility and distribution of the population (migration).

The goal of the increase in administration, registration, population statistics is the creation of a population registration system that is more perfect, and gradually the population registration is conducted in the city of Surabaya. Additionally, it is also directed to create a data bank of residence in the city of Surabaya for the purposes of planning, monitoring and evaluation of development (siduga). The cooperation between relevant agencies, Ministry of Home Affairs, BPS, and other agencies needs to be improved in order to create resourceful population information in Surabaya City.

In the arrangement of the population registration system in Surabaya City, the policy pursued is to have some kind of uniformity and quality of the information obtained, but the maintenance of diversity implementation is adapted to local conditions. Moreover, the policy is also directed to develop relationships among related agencies in the implementation of population registration.

In the civil registration of Surabaya City, the policy of education and training in the field of the population for society and government officials involved in the field of the population is much improved. Efforts to increase communication, information and education developed extensively and massively so as to reach all levels of society, including the executive officers and data users to find out more about the importance of data generated from the population registration for development in the city of Surabaya.

Policies and efforts to increase the ability of the centre of population studies as demographic data analysts in Surabaya along with the relevant agencies in the field of population intensified. Likewise, policies to improve the ability of managers of non-governmental organizations, particularly the institutions of society population, intended so that the participation and self-reliance can be more quickly achieved. For example, cooperation between Dispendukcapil of Surabaya City and BPS of Surabaya City, and NGOs in terms of analysing administrative records migration in Surabaya since 2010 until today.

Another important policy in the city of Surabaya is to create simple demographic indicators, relevant to sectoral development activities. In addition, it is also attempted so that the population indicators must be taken into consideration at the discretion of authorities. This effort is developed through the provision of population data that can directly be used by related sectors, such as inclusion in the information system of population and family (siduga).

The output expected from the management of population administration is the availability of data and documents processed well and properly (which means the data is complete, current, and reliable) (Sudirman, 2008: 6). The population database based on the regulation is binding and intended to make people aware of the population administration order. So, through the normative base, it is expected to create a legal certainty, to provide protection, and to drive people to participate in implementing population administration order, as well as to impose a sanction to the violator. Additionally, it is also expected for the realization of the quality improvement on population registration and civil registration, the provision of data for the development planning and government, as well as the implementation of data exchange in the system in order for the verification of individual data in public service in population sector.

According Wiyonoputro (2009: 59), to be able to realize the population administration that is effective, efficient, and accurate, it must meet several criteria, among others: (1) the authority of institutions and officials to serve enforcement documents, and (2) the use of citizenship documents must be appropriate with the standards and made in accordance with the facts.

Then, the research on population administration has been conducted quite often. According to a research by Rohman, Hanafi, and Hadi (2011: 101), population administration policies integrated in Malang City that focuses on basic services of ID card shows that the policy of centralization management of identity cards is a step forward for Malang government, especially in the field of public service to tidy up the system of administration into one central location for easy access to Malang City government, so that in making other policies, there is a concrete data. According to the research result by Lambelanova 
and Waworundeng (2014: 83), resident services of population administration in Manado still uses a standard based on MENPAN Decree No 63 of 2004, and as for the implementation of the service, it is not yet optimal, in which the service provided is not completely with Law No 24 of 2013, particularly in the service charge.

According to the research result by Slamet and Faiz (2012: 89), the use of information system of the population administration in the part of the migrating or coming of residents in Garut can help the division of population registration and census in managing the data of people move, people come, and the process of making reports. In addition, the information system can also easily generate reports on the information of the number of people coming or moving monthly or annually accurately, precisely, relevant, and as expected. A research by Junaidi (2015: 119) in terms of e-government, shows that the implementation of e-government in the service of the population administration has been implemented by the Department of Population and Civil Registration of Serdang Bedagai Regency since 2007, namely the use of ICT as SIAK and e-ID card in service. The benefit is increased efficiency, effectiveness, transparency, accountability, participation, security, and accuracy of demographic data. Supporting factors are the commitment of the leadership, budgets, policies, while human resources, infrastructure, and public awareness are the barrier to the implementation of e-government.

On the other hand, the web-based population administration service (online) is a breakthrough in order to improve people's satisfaction with the performance of the government of Candigatak Village, as well as optimizing the technology in the field of information and communication technology which, with the use of this community, can be served anytime and anywhere. The system developed is able to cater for a range of online population administration products, as well as directly, so that it will greatly facilitate the people. The system can also be arranged to process the transfer of population (births and deaths), and store the letters that were ever processed and then displayed in the form of reports that can be printed. With this system, various problems in the population administrative services in Candigatak Village can be resolved (Hidayatulloh and Mulyadi, 2015: 69).

The implementation of e-KTP in the Department of Population and Civil Registration of West Kutai Regency has been conducted as the specified mechanism but in a less than optimal implementation. The less than optimal implementation of the policy of e-KTP in the Department of Population and Civil Registration in West Kutai Regency caused by lack of alternatives and methods of socialization of the Department of Population and Civil Registration only relies on socializing face-to-face and billboards, do not use other media such as radio, and leaflets. Technical obstacles such as damage to the operational system of the registration computer and constraints of nontechnical in the research sites such as the weakness of the Internet and the destruction of the device/ computer components (hardware) so that the service of e-KTP delays, frequent power outages in West Kutai Regency, resulting in the data collection process and e-KTP data registration delays, and the still concentrated issuance of e-KTP in the community centre makes the people receive e-KTP late (Bastiar, Sutadji, and Irawan, 2014: 91-92).

Then, the research result by Ashari (2014: 92) suggests that the cause of the lack of maximum performance on the implementation of Electronic Identity Card registration in South Putussibau District is the number of compulsory data of ID cards that do not match the data in the Population Administration Information System (SIAK), so a lot of compulsory ID cards holders that do not have valid data. In this regard, Warman and Wiliandri (2011: 81) explains that the amount of data managed and the need to deliver information quickly in the activities on population administration makes information technology as a medium that is considered capable and reliable to assist in data management and presentation of information quickly, easily, and accurately.

The research results above show that the administration of population in some areas in Indonesia has not done well, and there are many obstacles that affect it. In addition, the research results have not reviewed all the principal dimensions of the implementation of population administrative policies as mandated by the regulation of Law No 24 of 2013 (still focuses on one dimension, such as ID cards or the institutional must be integrated). Therefore, this study sought to factually and empirically describe one basic dimension of the implementation of policies on population administration by taking the case in the city of Surabaya, which is the dimensions of migration (direction of mobility and distribution of the population), or the process of the population movement registration service out of the city of Surabaya and the newcomer residents in the city of Surabaya.

Furthermore, according to Situmorang (2009: 64), the dimensions of the implementation of population administration policies based on the Population Administration Information System (SIAK), what considered to be ideal is the service process of Indonesian population movements registration within the country's region and migrating citizens that are going well. The process of registration service on the birth that is going well, 
The process of service registration event of death that is going well, The process of Moslems marriage registration service that is going well, The process of Moslems divorce registration that is going well, and the process of the registration service of biographical data of population and family card (KK) and Identification Card (KTP) documents for Indonesian citizens effectively. The view is related to the main dimensions of the subject as may be drawn from the regulation of Law No 24 of 2013 and the Surabaya City Regulation No 14 of 2014.

\section{Method}

This study is a qualitative research (Creswell, 2014: 47). The research used is descriptive qualitative research, in the form of research with case study method or approach (Yin, 2014: 66) in Surabaya City, East Java Province, with the consideration that the region is the second largest city in Indonesia and has a high level of urbanization so that the problem of managing administration of residence is quite complex. Furthermore, the study was conducted for 1 (one) month, i.e. April 2015.

The data collection technique is conducted in two ways. First, in-depth interview using an interview guide to people who are competent in the implementation of population administration policies, which are limited only to Surabaya Dukcapil apparatus. Second, the literature study of the document. Third, the observation on Surabaya City Dukcapil in April 2015. The method of data processing and analysis used is a descriptive method.

\section{RESULT AND DISCUSSION}

Migration is the movement of people from one place to another. There are two (2) types of migration, i.e. immigration, and emigration. Immigration is the movement of people from other countries/regions visiting a country/region. For example, residents of East Java move and live in Jakarta. While emigration is the movement of people from one country/region to other countries/regions. So, just the opposite, i.e. Jakarta residents who emigrate to East Java.

Surabaya, as the second largest metropolitan city in Indonesia, is the centre of the first-order growth that has become a "magnet" for the strongest population in the buffer zone (hinterland), especially in rural areas around the city. The existence of Surabaya City is part of the urban area in Indonesia, particularly in Java Island. At the macro level, the growth of urban population in Java continues to grow so that Java has been dubbed as the urban island. They come to Surabaya since in that city, there are many options to get various opportunities in an effort to improve their lives. They come to the city of Surabaya with a variety of motives, despite the economic motive is the most dominant element. They have perceptions and expectations to earn a higher income than in their area of origin, especially rural areas.

Nevertheless, the rapid population growth of the city of Surabaya is attributed to the migration process, as well as natural increase. Surabaya city itself has evolved in the process of interaction of the components of the state population, technology, environment, and urban organizations that have spawned "ecological urban complex." Surabaya City is the capital city of East Java Province. Surabaya is the second largest city in Indonesia after Jakarta, with a land area of $333,063 \mathrm{~km} 2$ and a total population of more than 3 million inhabitants. Surabaya is the centre of business, trade, industry, and education area of eastern Java. With the characteristics of the city of Surabaya, they can pose a special attraction for migrants from outside the area to improve their welfare.

According to the department of population and civil registration (Dispendukcapil) of Surabaya City, in June 2013, the number of immigrants from outside the area moved to the city of Surabaya is more than 28,000 and not including the number of seasonal migrants who reach more than 3,000 people, the population growth the city of Surabaya in 2011 alone reached 3,024,000 inhabitants and for the year of 2012, the population growth in the city of Surabaya increased to $3,125,000$ people, in 2013 , the population growth of Surabaya increased to $3,166,000$ people. With this, the population growth for the city of Surabaya can be assumed to be increasing fairly sharp for each year which reached 50,000 people.

The problem factors of the total population growth are because of the increase in immigrants from outside the area to Surabaya and also due to the birth of the locals. But of the two factors, the most influential is the new residents coming into the city of Surabaya. And, the social problems of the population density is the existence of seasonal residents who immigrate to the city of Surabaya, and many of these seasonal residents do not have a definite place to stay and they also do not have definite jobs, therefore increasing the number of unemployment.

With the state of the population growth in the city of Surabaya, which can be assumed to be overpopulated, Surabaya City Government should take an action so that the population growth in Surabaya does not get worse. One of the actions that have been carried out by the government of Surabaya City is unofficial residents or seasonal residents in the city of Surabaya, which are not recorded in sub-villages, districts, and by the local population and civil registration (Dispendukcapil), that is by requiring them to process the seasonal 
residents' identity card (Kipem), if they do not take care of it, the seasonal residents will be deported to their regions of origin.

Furthermore, population mobilization data in Surabaya City obtained from Surabaya Dukcapil (2015: 137) concerning the movement of people and settlers in the city in 2014 is those coming are as much as 67,416 people, while those moving are 31,284 people. This indicates that the mobilization of the population regarding the population is that those moving are more than the population of migrants in the city of Surabaya in 2014.

The process of Indonesian population movement in Indonesia regions and settlers in the city of Surabaya must meet the requirements determined, namely with a letter of introduction from RT/RW, photograph, ID card, family card, a letter of good conduct from local police (for immigrants), as well as filling form provided. If the requirement or procedure have been met, then the registrar staff (administrative officer) keep records on the list of residents in the sub-village big book. The result of the registration then proceeds to the District Office, and for the ID card and family card in the district and sub-district, there is a verifier for granting or affixing a signature ID cards or KK. In addition, there is another officer who acts as the operator in a Place for Demographic Data Registration (TPDK), which is attached to the subdistrict level services. So TPDK service is not in the village but in the District.

In terms of requirements or procedures as mentioned above are obvious, including in its administration in a list of national identification (Population Data Book and Population Data Summary Book) at Sub-Village Offices and at the District Office. However, for the service, still found some weaknesses complained by local residents. Registration service of residents' mobility and migrants, often the residents are sluggishly served by the registrar, sometimes even the officers are not in place so they have to wait quite long, and sometimes also charged that should not exist.

On the other hand, sometimes Population Data Book is not stored in place so that if necessary must be sought in advance, there is a page with irregular serial number of the registration, there are a few records that are forgotten to be equipped with a registration date and initials of registration staff, and sometimes the result of the registration is submitted late to the District Office, in which it is important for direct entry at the district level.

The above condition indicates that the implementation of the migration policy of administrative registration in Surabaya in terms of the service for registration process of population movements within the Indonesian citizen and immigrant population is still not good. Because, although in terms of requirements or procedures are clear, but for the services, still found some weaknesses that got complaints by local residents in the city of Surabaya.

Actually, the perfection of the population administration system plays an important role in supporting the population program management policies. With the improvement of the system of administration of basic data on population, among other things about mobility, will be known accurately. One population administration program in the city of Surabaya is a seasonal population census program called KIPEM. However, this KIPEM program has not been effective to put seasonal residents into inventory and the benefits are not clear on the program, so its role should be criticized.

This study shows that not all migrants, who are seasonal, in the city of Surabaya with KIPEM card. Even, many migrants who maintain the identity card of their origin despite a long stay in the city of Surabaya, by expressing a variety of reasons. If only the seasonal migrants feel the tangible benefits with ownership KIPEM, then they will automatically take care of it.

The issue needs to be raised in order to dispel thoughts of a dichotomy between the citizens of Surabaya with non-permanent migrant or often called seasonal migrant citizens, which has led to discriminatory treatment. Social facts indicate that seasonal citizens are Indonesian citizens whose lives are less fortunate that they must also have the same right to protection from the government and the right to develop, among others, in the city of Surabaya. When KIPEM program is indeed beneficial for seasonal migrants, of course, needed to increase socialization of the rule either in the pockets of settlements in the city of Surabaya as well as potential areas from which they come.

Non-permanent migrants who live in an area of illegal settlements in the city of Surabaya which is often referred to as spontaneous residents or popularly known as seasonal migrants are still bound to the life of their native region. Hence, most of them do not have identity cards (KTP) in Surabaya. On the basis of KTP ownership, Surabaya City Government has the policy to give priority in obtaining or utilizing aid, public facilities, and subsidies. Although there is a discriminatory policy, but in reality, most of the seasonal residents can come to enjoy. In this case, it is suggested that the government is not strict between the city of residence status with the rights of their citizens. Population regulation that is not followed by the decisiveness in the implementation, of course, have made a conducive condition to migration entering into the city of Surabaya, which in turn gives rise to various urban problems, such as insufficient provision of social facilities, the emergence of land 
conflicts, reduction in the carrying capacity of the environment, and rising unemployment.

Seasonal residents who generally live in marginal conditions are required to have Seasonal Resident Identity Card (KIPEM), but to take care of KIPEM, let alone become the citizens of Surabaya, is not simple. They have to sacrifice some funds and the processing time is considered to be quite burdensome. In addition, by retaining as seasonal residents, meaning they do not lose their status as residents of their home areas. By having the origin KTP, meaning they still have the right to conduct the affairs in the area of origin, such as choosing the head of the village, take care of ownership asset and take care of the cemetery. Therefore, although de facto they live in the city of Surabaya, but they are still tied to the region of origin, even occurred the flow of remittances both money and goods, and the delivery of ideas about life in Surabaya. In such circumstances, then this has led to ruralurban migration process in a "gandeng-ceneng" (chain migration). Not all immigrants in the city of Surabaya, (although they have long lived in the city of Surabaya, even have a house), have KIPEM. Therefore, in reality, the number of seasonal migrants in Surabaya is above statistical data based on KIPEM ownership.

Furthermore, there are a number of factors supporting and hindering the implementation of the administrative records of migration policy in the city of Surabaya. First, the supporting factors. Based on the result of the author's interview with an informant of Surabaya City Dukcapil Apparatus (April 2015), obtained the information on a number of factors that could support the implementation of the migration policy of administrative registration in the city of Surabaya.

Regulation Clarity. The implementation of administrative registration on population migration in the city of Surabaya is set nationally and obviously through the regulation of Law No 24 of 2013 and the Surabaya City Regulation No 14 of 2014, including the implementation guidelines, each of which is directed by the leadership of government agencies, that is the further assignment of Mayor to the subvillage chiefs in the organization of information on population administration in Surabaya City. The regulation clarity should be able to support the implementation of administrative registration on the population migration in Surabaya City in order to improve the quality of services for population registration and civil registration, to provide data for the development planning and governance, and the implementation of systemized data exchange in order to verify the data of individuals in the public service in Surabaya City. But in fact, the clarity of the regulation has not been fully put to good use in order to support the implementation of administrative registration on migration in Surabaya City.

Facility Adequacy. The implementation of administrative registration on population migration in the city of Surabaya requires information and communication technologies to facilitate the management of information on population administration in the city of Surabaya, especially for the benefit of SIAK connected because of the facility of electricity, means of computers, and data communication networks. In addition, it must be supported by the software, forms, and population documents blanks. Facts in the field indicate that there are actually a variety of tools that can support the implementation of administrative registration on population migration in the city of Surabaya as there are 14 pieces of wood file cabinets, 43 pieces of manual 16 inc typewriter, 15 pieces of manual 26 inc typewriter, 7 pieces of rig communication tools, 10 pieces of computer and printer, 17 telephones, and 15 fax machines. However, all this time, the adequacy of the means has not been fully utilized to the maximum in order to support the implementation of administrative registration of population migration in the city of Surabaya.

Cost Adequacy. Surabaya Mayor is responsible for provisioning costs of implementation of population tasks in the city of Surabaya, including for the purpose of providing population data communication costs. The head of sub-villages admitted that the costs prepared every year for organizing orderly population administration in the city of Surabaya are sufficient to be used in the provision of hardware, software, forms, demographic books, and population document blanks. The adequacy of the charge should be able to support the implementation of administrative registration of population migration in Surabaya over the years. But in fact, not been fully used to the maximum by the offices of the sub-village.

Implementer Capability. The success of the implementation of administrative registration on population migration in the city of Surabaya must be supported by the availability of executive officers who have the adequate capability in the field of population administration, which among other things can be obtained through the Population Training organized by the government. All employees of the sub-village offices who are concerned with the field of population administration tasks have been following the Population Training in stages since 2010. It should have supported the implementation of administrative registration of migration in Surabaya all this time, but in fact, it has not been fully utilized to the fullest by the sub-village offices of which have followed the Population Training.

Second, a limiting factor. The result of the author's interviews with informants from apparatus of Surabaya City's Dukcapil Surabaya (April 2015), 
obtained information on a number of factors that still impede the implementation of administrative records on population migration in the city of Surabaya.

Low Community Participation. The people of Surabaya is expected to play a part in supporting the implementation of administrative registration of population migration in Surabaya City, including for the purpose of dissemination of information and education activities as well as providing means to support local authorities in the management of information on population administration in the city of Surabaya. All this time, some residents of the city of Surabaya, especially migrants, are less involved in supporting local governments to the implementation of administrative registration of population migration in the city of Surabaya, such as neglecting or not serious in completing the form of bio population, unwilling to take care of the family cards and the extension of their identity cards, no arrival reports (for migrants), unwilling to take care of their family's birth certificates, do not attempt to set up a requirement of residence which has been set, and so on. Such things can obviously affect population archiving and administrative order in the city of Surabaya over the year.

Low Implementation Commitment. To achieve the implementation of a good administrative registration on population migration in the city of Surabaya, it is necessary to have high commitment (consistency and consequences) of the population executives in Surabaya City (particularly the staff of the registrar), including of course for implementers at the district and the Office levels in carrying out population registration and administrating tasks. All this time, the implementers in sub-villages do not have a high commitment to the task, among other things, the service sometimes is slow, the slow pace in the preparation of population reports, do not provide information on population administration in the form of pictures and graphics, poorly maintained/irregular population archives that have been noted, the still frequent fee charging beyond the actual administrative costs, etc. Things like that really affect the implementation of administrative registration of population migration in the city of Surabaya.

The lack of executive officers. Surabaya Mayor is responsible for performing the task of implementing the provision of human resources on record keeping and administration of population in sub-villages, such as registrar staff and other field personnel. In reality, in sub-village still shows that they lack the resources on the execution of population duties, with an average of only 5 people (Head of Government Sub-Division, Head of Public Service Sub-Division, Head of Population SubDivision, and each only 1 staff of Sub-Government and Sub-Public Services Section). In comparison with the large population in the city of Surabaya, the number of personnel is still minimal.

Population characteristics. Surabaya City as the capital of East Java province clearly has the characteristics of the population that is unique and complex. This happens because of a heterogeneous population with a culture of their respective regions. This diversity also caused residents in the city of Surabaya to have varied individual characteristics and levels of awareness, including due to the high intensity of job seekers and the effect of economic conditions that are more complicated in Surabaya. In such circumstances, there are still many residents of Surabaya, with a low population awareness. They are indifferent to the administrative order of population, and for them, work and financial factor are most important things. As a result, many people ignore or do not seriously complete the form of bio population, unwilling to deal with the family cards and the extension of their identity cards, do not report their arrival (for migrants), unwilling to take care of birth certificate of their family, etc. Things like that obviously greatly affect the implementation of population migration administrative registration in Surabaya over the years.

\section{Conclusion}

In general, the implementation of the policy of population migration administrative records in Surabaya for this is still classified as less good, because there are still many weaknesses in its implementation. In the implementation of the registration service of mobility and the migrant population, often time the residents are sluggishly served by the registrar. The policy requires the administration of residents' ID cards, migrating or coming to Surabaya, needs to be conducted well. For example, if migrants do not take care of the resident's identity must be sent back to their regions of origin. The potential factors supporting the implementation of administrative records of the population of Surabaya City migration are clarity of rules, adequacy of facilities, adequacy of costs, and the ability of implementers. Meanwhile, the inhibiting factors are the lack of community participation, lack of executive commitment, lack of executive officers, and the characteristics of the population.

\section{ACKNOWLEDGEMENT}

Thank you for the Faculty of Social and Political Science of UNTAG for funding this journal. 


\section{REFERENCES}

Ashari, A. (2014). Implementasi Program Kartu Tanda Penduduk Elektronik di Kecamatan Putussibau Selatan Kabupaten Kapuas Hulu. Jurnal Administrasi Publik Dan Birokrasi, 1(1). Retrieved from http://pasca.ut.ac.id/journal/ index.php/JAPB/article/view/23.

Bastiar, M, S., \& Irawan, B. (2014). Implementasi Kebijakan e-KTP dalam Mewujudkan Tertib Administrasi Kependudukan di Dinas Kependudukan dan Pencatatan Sipil Kebupaten Kutai Barat. Ejournal Administrative Reform, 2(3), 1967-1979. Retrieved from http:// ar.mian.fisip-unmul.ac.id/site/?p=824.

Creswell, J. (2014). Research Design: Qualitative, Quantitative, and Mixed Methods Approaches (4th ed.). NY: SAGE Publications.

Dispendukcapil Kota Surabaya,. (2014). Surabaya City Regulation No 14 of 2014 on the Amendment of Surabaya City Regulation No 5 Year 2011 on the Implementation of the Population Administration. Surabaya: Dispendukcapil Kota Surabaya.

Dispendukcapil Kota Surabaya,. (2015). Laporan Kependudukan Kota Surabaya Tahun 2015. Surabaya: Dispendukcapil Kota Surabaya.

Ediastuti, E. (2012). Pola dan Trend Demografi Indonesia. In A. Dwiyanto, Penduduk dan Pembangunan. Yogyakarta: Aditya Media.

Effendi, T. (2012). Perkembangan Penduduk, Sektor Informal, dan Kemiskinan Kota. In A. Dwiyanto, Penduduk dan Pembangunan. Yogyakarta: Aditya Media.

Hidayatulloh, S. \& Mulyadi, C. (2015). Sistem Pelayanan Administrasi Kependudukan Desa Candigatak Berbasis Web. Jurnal IT CIDA, 1(1), 42-55. Retrieved from http://journal. amikomsolo.ac.id/index.php/itcida/article/ view/1.

Junaidi,. (2015). Implementasi Electronic Government untuk Penyelenggaraan Pelayanan Administrasi Kependudukan. Reformasi, 5(1), 169-182. Retrieved from http://jurnal.unitri. ac.id/index.php/reformasi/article/view/74.

Kasto,. (2012). Proyeksi Penduduk dan Rumah Tangga Indonesia. In A. Dwiyanto, Penduduk dan Pembangunan. Yogyakarta: Aditya Media.

Keban, Y. (2012). Analisis Urbanisasi di Indonesia: Periode 1980-1990. In A. Dwiyanto, Penduduk dan Pembangunan. Yogyakarta: Aditya Media.

Lambelanova, R. \& Waworundeng, M. (2014).
Pelayanan bagi Penduduk Rentan Administrasi Kependudukan Pasca Bencana Tahun 2013 di Kota Manado Provinsi Sulawesi Utara. Jurnal Dukcapil, 2(2), 19-40. Retrieved from http://jurnal.ipdn.ac.id/2015/01/jurnalkependudukan-dan-catatan-sipil-vol-2no-2-2014/.

Mantra, I. (2012). Dampak Pembangunan terhadap Mobilitas Penduduk. In A. Dwiyanto, Penduduk dan Pembangunan. Yogyakarta: Aditya Media.

Minister of Law and Human Rights,. (2013). Law No 24 of 2013 on the Amendment of the Law No 23 of 2006 concerning Population Administration. Jakarta: Ministry of Law and Human Rights.

Rohman, D., Hanafi, I., \& Hadi, M. (2013). Implementasi Kebijakan Pelayanan Administrasi Kependudukan Terpadu (Studi pada Dinas Kependudukan dan Catatan Sipil Kota Malang). Jurnal Administrasi Publik, 1(5), 962-971. Retrieved from http:// administrasipublik.studentjournal.ub.ac.id/ index.php/jap/article/view/172.

Situmorang, S. (2009). Simulasi Sistem Administrasi Kependudukan. Jurnal Administrasi Kependudukan, 1(1), 39-40.

Slamet, D., Retnadi, E., \& Partono,. (2012). Pengembangan Sistem Informasi Administrasi Kependudukan (SIAK) pada Bagian Pendaftaran Pindah Datang Penduduk di Dinas Kependudukan dan Pencatatan Sipil Kabupaten Garut. Jurnal Algoritma, 9(4), 1-10. Retrieved from http://jurnal.sttgarut.ac.id/ index.php/algoritma/article/view/5.

Sudirman, U. (2008). Cegah KTP Berganda, SIAK Diluncurkan. Jurnal Administrasi Kependudukan, 1(1), 11.

Warman, I. \& Wiliandri,. (2011). Sistem Informasi Administrasi Kependudukan Kota Padang (Studi Kasus: Kecamatan Nanggalo). Jurnal Teknologi Informasi dan Pendidikan, 3(1). Retrieved from http://jurnal-tip. net/?modul=jurnal\&id=65.

Wilopo, S. (2012). Kebijakan Kependudukan Indonesia. In A. Dwiyanto, Penduduk dan Pembangunan. Yogyakarta: Aditya Media.

Wiyonoputro, W. (2009). Masih Terfokus Komputerisasi KTP. Jurnal Administrasi Kependudukan, 1(1), 33-34.

Yin, R. (2014). Case Study Research: Design and Methods (Applied Social Research Methods) (5th ed.). NY: Sage Publications, Inc. 